Monika Hamerska 1

Article info:

Received 23.08.2019

Accepted 18.01.2020

$\mathrm{UDC}-65.011$

DOI - 10.24874/IJQR14.02-14

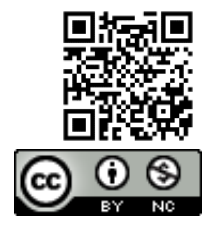

\section{IDENTIFICATION OF SCIENTIFIC PRODUCTIVITY DETERMINANTS}

\begin{abstract}
The increasing role of science in creating social and economic development and its important role for knowledge-based economy has contributed to the development of the research on scientific productivity. A particularly important aspect of the research in this area is the analysis of determinants affecting the level of individual productivity, which is important not only in the context of scientists evaluation but also affects the evaluation of scientific units and their position in international rankings.

The identification of the most important determinants of scientific productivity is the main goal of the paper. The productivity was expressed by various measures related to publication activity of the researcher from the Cracow University of Economics in the time period from 2004 to 2015. All calculations were performed with the use of $R$ software.
\end{abstract}

Keywords: Scientific productivity; Determinants; Measures of scientific productivity

\section{Introduction}

Issues related to the concept of scientific productivity are popular among universities, research institutes, government agencies and international institution. It is related to the increasing role of science in creating social and economic development and its important role for knowledge-based economy, in which resource allocation is extremely important in the context of limited outlays and achieving the best results.

Scientific productivity attracts much attention in the social research but is rarely directly defined in the scientific literature. The perception of productivity depends on work context (academic vs. non-academic), individual attributes (young vs. senior researchers), professional affiliation (scientists vs. engineers) and research characteristics (theoretical vs. experimental, externally vs. internally funded research) (Shenhav \& Haberfeld, 1988). In the literature, scientific productivity is most often described as the number of scientific publications determined at the level of a researcher or institution. Widely regarded as the main source of esteem, as a requirement for individual promotion, as evidence of institutional excellence, and as a sine qua non for obtaining competitive research funds, publication is central to scholarly activity and recognition (Ramsden, 1994). Scientific productivity may be defined as a quantity indicator used for measuring scientific achievements and for evaluating scientific activity by the number of citations of the researcher's work or by the number of published scientific papers.

The concept of productivity, was transforming over one hundred years and this transformation occurred in four steps (Godin, 2009):

1. Productivity as reproduction

2. Productivity as output

3. Productivity as efficiency

4. Productivity as outcome

1 Corresponding author: Monika Hamerka

Email: monika.hamerska@uek.krakow.pl 
Table 1 presents methods of measuring scientific productivity, associated with stages of its evolution.

Table 1. Measures of Scientific Productivity

\begin{tabular}{|l|l|l|}
\hline $\begin{array}{l}\text { Approach to } \\
\text { the Concept } \\
\text { of Scientific } \\
\text { Productivity }\end{array}$ & $\begin{array}{c}\text { Criterion for } \\
\text { Measuring } \\
\text { Productivity }\end{array}$ & $\begin{array}{l}\text { Measures of } \\
\text { Scientific } \\
\text { Productivity }\end{array}$ \\
\hline $\begin{array}{l}\text { Productivity } \\
\text { as } \\
\text { Reproduction }\end{array}$ & Men of science & $\begin{array}{l}\text { Number of } \\
\text { employees of } \\
\text { science, } \\
\text { Number of } \\
\text { eminent } \\
\text { scientist }\end{array}$ \\
\hline $\begin{array}{l}\text { Productivity } \\
\text { as Output }\end{array}$ & $\begin{array}{l}\text { Scientific } \\
\text { achievements }\end{array}$ & $\begin{array}{l}\text { Scientific } \\
\text { publications } \\
\text { (bibliometric } \\
\text { indicators), } \\
\text { patents }\end{array}$ \\
\hline $\begin{array}{l}\text { Productivity } \\
\text { as Efficiency }\end{array}$ & $\begin{array}{l}\text { Effectiveness } \\
\text { of the research } \\
\text { process }\end{array}$ & $\begin{array}{l}\text { Rate of } \\
\text { return }\end{array}$ \\
\hline $\begin{array}{l}\text { Productivity } \\
\text { as Outcome }\end{array}$ & $\begin{array}{l}\text { Economic } \\
\text { development }\end{array}$ & $\begin{array}{l}\text { Labor } \\
\text { productivity } \\
\text { rate } \\
\text { Multifactor } \\
\text { productivity } \\
\text { (MFP) } \\
\text { Economic } \\
\text { growth rate }\end{array}$ \\
\hline & & \\
\hline
\end{tabular}

Source: own study based on (Godin, 2009)

At present, the majority of scientific measures used in practice, are based on the concept of "productivity as output" and "productivity as efficiency". In the literature, bibliometricrelated indicators account for the most often used measure of productivity. In scientific studies, the productivity is also expressed with the use of the number of patents but it is not a common practice.

In the related literature, the following considerations related to differences in the level of individual scientific productivity are found:
1. Accumulative advantage theory;

2. Reinforcement theory;

3. The sacred spark theory;

4. Advantage maximising theory.

Accumulative advantage theory is often referred to the theory of the Matthew effect. It was taken from the Bible and refers to wealth: "the rich get richer and the poor get poorer". In the case of a study of productivity related to science, " Matthew effect" or the mechanism of accumulation of advantages defined by Robert K. Merton refers to the situation when eminent scientists receive more merit than relatively unknown ones, even if their work is at a similar level. As a result, the following regularity is related to the level of individual scientific productivity: scientists who in the past were characterised by high scientific productivity in the future become even more productive, while low levels of productivity causes even lower level in the future.

Features associated with the presented theory may be written in the form of the following regularities:

- Eminent scientists will often get more credit than a comparatively unknown researcher, even if their work is similar (Merton, 1968);

- Accumulation of benefits relates to the way in which some scientists are able to acquire resources for their research, which leads to even more successful research and subsequent publications (Gaston, 1978).

Criticism of the theory of cumulative benefits refers to the fact that it cannot be assumed that the accumulation of advantages will be reflected only by an increase in productivity expressed in the number of publications or the number of citations. After reaching a certain level of scientific development expressed by a significant number of recognised scientific publications, their author can use the theory of cumulative benefits to gain scientific awards, prestigious positions in organisations or recognised scientific journals (Mittermeir \& Knorr, 1979). 
Literature related to scientific productivity often equates the cumulative advantage theory with reinforcement theory.

Reinforcement theory was proposed in psychology by B. F. Skinner and states that award-winning behaviour continues when unrewarded behaviour ceases (Skinner, 1938). In the context of scientific productivity, the theory of reinforcement refers to a situation in which the level of the author's later productivity is significantly influenced by the recognition of his or her earlier works. Scientists whose work has often been cited maintain a high level of scientific productivity, while the level of productivity of people whose work is not cited decreases (Cole \& Cole, 1973). According to Gaston, the theory of reinforcement attempts to answer the question about the reasons for the continuation of scientific activity by researchers and publishing new papers, while the theory of cumulative advantage indicates how scientists are able to obtain funds that will facilitate their research and the possibilities of publishing the results of these studies (Gaston, 1970) for (Sridhar, 2009).

Reflections on The sacred spark theory as theories explaining differences in the level of individual scientific productivity may be found for the first time in the paper from 1973 , in which the authors claim that high productive researchers have "an inner drive to do science and by a sheer love of the work" (Cole \& Cole, 1973).

In later works references to the above concept formulated may be found as follows:

- There are significant, predetermined differences between scientists regarding their ability and motivation for creative scientific research (Allison \& Stewart, 1974);

- Productive scientists are a highly motivated group of researchers and have the necessary endurance or the ability to work hard and perseverance in the pursuit of farreaching goals (Fox, 1983);
- There is general agreement that some people are particularly good at creating science, and that some are not just good but excellent (Stephan \& Levin, 1992).

The last of the concepts mentioned above is Advantage maximising theory, which assumes that:

- All researchers reduce researchoriented efforts over time because they think other tasks may be personally more beneficial for them;

- Eminent researchers may have few incentives to write a new article or book because it will not improve the high professional reputation that they already have (Kyvik, 1990);

- Later in the career, scientists are less financially motivated to conduct research. With each additional year, the reward for conducting scientific research decreases (Stephan \& Levin, 1992).

Marek Kwiek believes that the theory of maximising benefits fits the situation in Poland very well. The motivation to conduct research has been extremely low in the last two decades and the motivation to conduct additional education of students in the private sector, extremely high (Kwiek, 2015). The mentioned theories of research productivity are complementary to each other, not competitive: they all apply to varying degrees to the European academic staff, including academic staff in Poland (Kwiek, 2015).

\section{Scientific Productivity Research}

British scientist Francis Galton first initiated the approach of scientific productivity determined by the degree of reproduction of scientific staff. Based on this approach, scientific productivity was expressed by the number of eminent scientists. In 1906, James Cattell, the editor of Science, published the American Men of Science, a journal containing a bibliographic description of the US scientists used for the first systematic 
quantitative research on science (Godin, 2007). Based on the developed data, Catell had conducted regular scientific research until 1930, in which the measurement of scientific productivity was expressed in the number of scientists, their geographical distribution, and productivity (Godin, 2006). Catell defined the measurement of scientific productivity in the context of quantity understood as: the number of people of science and quality, defined as a contribution to science.

In 1926, Alfred James Lotka published the paper entitled The Frequency Distribution of Scientific Productivity in the Journal of the Washington Academy of Science. At work, Lotka identified and described the pattern which was characteristic for science development. The law under the name of Lotka's law or Lotka's inverted square law became one of the fundamental laws in bibliometrics. Lotka conducted the study based on two indexes: Index of Chemical Abstract 1907-1916 and Index of Auerbach's Geschichtstafeln der Physik from the beginning of the index until 1900 .

On the basis of the results he obtained, Lotka proposed a general rule regarding to relations thus found to exist between frequency y of persons making $\mathrm{x}$ contributions (Lotka, 1926):

$$
x^{n} * y=c
$$

$\mathrm{y}$ - number of authors who published $\mathrm{x}$ publications

$\mathrm{n}, \mathrm{c}-$ parameters specific to the analysed publication sets

After more accurate calculations, A.J.Lotka determined that for chemistry, the c parameter was $0,56669, \mathrm{n}$ was 1,888 and for physics c= 0,6079, n=2,02 (Nowak, 2008)

Lotka wrote in his publication (Lotka, 1926): In the cases examined it is found that the number of persons making 2 contributions is about one-fourth of those making one; the number making 3 contributions is about oneninth, etc. The number making $n$ contributions is about $\frac{1}{x^{2}}$ of those making one and the proportion of all contributors, that make a single contribution is about $60 \mathrm{per}$ cent.

Initially, Lotka's work had remained unnoticed for many years. In 1978, the first issue of the Scientometrics journal featured 437 bibliographic references referring to works investigating Lotka's law. From then on, the law was verified in various fields: IT, medicine, biochemistry, entomology, econometrics, literature related to obtaining patents (Vilachy, 1978) for (Pillai Sudhier, 2013). Table 2 presents examples of works from very rich scientific literature verifying Lotka's law.

Table 3 provides an overview of research on scientific productivity over time.

Table 2. Examples of scientific publications verifying Lotka's law, own study

\begin{tabular}{|l|l|l|l|}
\hline \multicolumn{1}{|c|}{ Authors } & \multicolumn{1}{|c|}{ Publication } & Study Area & \multicolumn{1}{c|}{ Results } \\
\hline (Murphy, 1973) & $\begin{array}{l}\text { Lotka's Law in the Humanities, } \\
\text { Journal of American Society for } \\
\text { Information Science }\end{array}$ & $\begin{array}{l}\text { Humanities } \\
\text { science }\end{array}$ & Verified positively \\
\hline $\begin{array}{l}\text { (Radhakrishnan \& } \\
\text { Kernizan, 1979) }\end{array}$ & $\begin{array}{l}\text { Lotka's Law and computer } \\
\text { science literature, Journal of } \\
\text { American Society for Information } \\
\text { Science }\end{array}$ & $\begin{array}{l}\text { Technical } \\
\text { sciences }\end{array}$ & $\begin{array}{l}\text { Positively verified when } \\
\text { considering the publication } \\
\text { of authors in one journal; } \\
\text { Negatively verified when } \\
\text { considering authors' } \\
\text { publications in various } \\
\text { journals }\end{array}$ \\
\hline
\end{tabular}


Table 2. Examples of scientific publications verifying Lotka's law, own study (continued)

\begin{tabular}{|c|c|c|c|}
\hline Authors & Publication & Study Area & Results \\
\hline$(\mathrm{Pao}, 1986)$ & $\begin{array}{l}\text { An empirical examination of } \\
\text { Lotka's Law, Journal of American } \\
\text { Society for Information Science, }\end{array}$ & 48 data sets & $\begin{array}{l}\text { Most data sets } \\
\text { verified } \\
\text { positively }\end{array}$ \\
\hline $\begin{array}{l}\text { (Gupta, } \\
\text { 1987) }\end{array}$ & $\begin{array}{l}\text { Lotka's law and productivity } \\
\text { patterns of entomological research } \\
\text { in Nigeria for the period, 1900- } \\
1973 \text {, }\end{array}$ & $\begin{array}{l}1720 \text { publications in the field of } \\
\text { entomology in } 1900-1973 \text { in } \\
\text { Nigeria }\end{array}$ & $\begin{array}{l}\text { Negatively } \\
\text { verified }\end{array}$ \\
\hline $\begin{array}{l}\text { (Kyvik, } \\
1989 \text { ) }\end{array}$ & $\begin{array}{l}\text { Productivity differences fields of } \\
\text { learning, and Lotka's law, } \\
\text { Scientometrics, Volume 15, Issue 3- } \\
4\end{array}$ & $\begin{array}{l}\text { Field of natural sciences, } \\
\text { medical sciences, social sciences } \\
\text { and humanities in 1971-1981 }\end{array}$ & $\begin{array}{l}\text { Negatively } \\
\text { verified }\end{array}$ \\
\hline $\begin{array}{l}\text { (Gupta, } \\
\text { 1989) }\end{array}$ & $\begin{array}{l}\text { Lotka's Law and Its application to } \\
\text { Author Productivity Distribution of } \\
\text { Psychological Literature of Africa, } \\
\text { 1966-1975 }\end{array}$ & Humanities in 1966-1975 & $\begin{array}{l}\text { Verified } \\
\text { positively }\end{array}$ \\
\hline $\begin{array}{l}\text { (Patraa \& } \\
\text { Chandb, } \\
\text { 2006) }\end{array}$ & $\begin{array}{l}\text { Library and Information } \\
\text { Science Research in India: A } \\
\text { bibliometric study. }\end{array}$ & $\begin{array}{l}\text { Scientific literature from India } \\
\text { based on the Library and } \\
\text { Information Science Abstracts } \\
\text { database from 1967-2004 }\end{array}$ & $\begin{array}{l}\text { Verified } \\
\text { positively }\end{array}$ \\
\hline $\begin{array}{l}\text { (Kumar, } \\
\text { 2010) }\end{array}$ & $\begin{array}{l}\text { Applicability to Lotka's law to } \\
\text { research productivity of Council of } \\
\text { Scientific and Industrial Research } \\
\text { (CSIR) }\end{array}$ & $\begin{array}{l}\text { The study concerned scientific } \\
\text { unit - Council of Scientific and } \\
\text { Industrial Research }\end{array}$ & $\begin{array}{l}\text { Negatively } \\
\text { verified }\end{array}$ \\
\hline
\end{tabular}

Table 3. Temporal approach to research on scientific productivity, own study

\begin{tabular}{|c|c|c|c|}
\hline Year & Research areas & Publication & Author/Precursor \\
\hline 1874 & \multirow{2}{*}{$\begin{array}{l}\text { The concept of scientific productivity } \\
\text { determined by the degree of } \\
\text { reproduction of scientific staff }\end{array}$} & $\begin{array}{l}\text { English Men of Science, } \\
\text { Mcmillan\&Co. Londyn }\end{array}$ & (Galton, 1874) \\
\hline 1883 & & $\begin{array}{l}\text { Inquiries into Human Faculties } \\
\text { and its Development, } \\
\text { Mcmillan\&Co. Londyn }\end{array}$ & (Galton, 1883) \\
\hline 1903 & $\begin{array}{l}\text { Scientific productivity measured by } \\
\text { the number of publications }\end{array}$ & $\begin{array}{l}\text { Statistics of American } \\
\text { Psychologists, American Journal } \\
\text { of Psychology }\end{array}$ & (Cattell, 1903) \\
\hline 1906 & $\begin{array}{l}\text { Catalog of men of science, used in the } \\
\text { first quantitative studies of science }\end{array}$ & $\begin{array}{l}\text { American Men of Science: A } \\
\text { Biographical Directory, New } \\
\text { York: The Science Press. }\end{array}$ & (Cattell, 1906) \\
\hline 1910 & $\begin{array}{l}\text { The second edition of the directory, } \\
\text { which made it possible to develop the } \\
\text { first statistical comparisons over time }\end{array}$ & $\begin{array}{l}\text { A Further Statistical Study of } \\
\text { American Men of Science, } \\
\text { Science }\end{array}$ & (Cattell, 1910) \\
\hline
\end{tabular}


Table 3. Temporal approach to research on scientific productivity, own study (continued)

\begin{tabular}{|c|c|c|c|}
\hline Year & Research areas & Publication & Author/Precursor \\
\hline 1915 & $\begin{array}{l}\text { Research related to the profile of } \\
\text { the researcher in terms of the } \\
\text { family, citizenship, family size, } \\
\text { marital status, age }\end{array}$ & $\begin{array}{l}\text { Families of American Men of } \\
\text { Science: Origin, Heredity and } \\
\text { Performance, }\end{array}$ & (Cattell, 1915) \\
\hline 1926 & The law of scientific productivity & $\begin{array}{l}\text { The Frequency Distribution of } \\
\text { Scientific Productivity, Journal of } \\
\text { the Washington Academy of Science }\end{array}$ & (Lotka, 1926) \\
\hline 1939 & $\begin{array}{l}\text { The first models of production } \\
\text { functions using science for }\end{array}$ & $\begin{array}{l}\text { Business Cycles: A Theoretical, } \\
\text { Historical, and Statistical Analysis of } \\
\text { the Capitalist Process, New York: } \\
\text { McGraw-Hill, Volume } 1\end{array}$ & $\begin{array}{l}\text { (Schumpeter, } \\
1939)\end{array}$ \\
\hline 1957 & economic & $\begin{array}{l}\text { Technical Change and the Aggregate } \\
\text { Production Function, Review of } \\
\text { Economics and Statistics, } 39\end{array}$ & (Solow, 1957) \\
\hline 1955 & Impact Factor & $\begin{array}{l}\text { Citation Indexes for Science A New } \\
\text { Dimension in Documentation } \\
\text { through Association of Ideas } \\
\text { Science, Science }\end{array}$ & (Garfield, 1955) \\
\hline 1962 & $\begin{array}{l}\text { The first edition of the Frascati - } \\
\text { recommendations on the use of } \\
\text { statistical methods to measure } \\
\text { science }\end{array}$ & $\begin{array}{l}\text { The Measurement of Scientific and } \\
\text { Technical Activities: Proposed } \\
\text { Standard Practice for Surveys of } \\
\text { Research and Development, Paris. }\end{array}$ & $(\mathrm{OECD}, 1962)$ \\
\hline 1963 & Modified Lotka's law & $\begin{array}{l}\text { Little science, big science, New } \\
\text { York, Columbia Univ. Press. }\end{array}$ & (Price, 1963) \\
\hline 1968 & Accumulative advantage theory & $\begin{array}{l}\text { The Matthew Effect in Science. The } \\
\text { reward and communication systems } \\
\text { of science are considered, Science. }\end{array}$ & (Merton, 1968) \\
\hline 1969 & Bibliometrics & $\begin{array}{l}\text { Statistical bibliography or } \\
\text { bibliometrics?, Journal of } \\
\text { Documentation. }\end{array}$ & (Pritchard, 1969) \\
\hline 1973 & Reinforcement theory & $\begin{array}{l}\text { Social Stratification in Science, } \\
\text { University of Chicago Press. }\end{array}$ & $\begin{array}{l}\text { (Cole \& Cole, } \\
\text { 1973) }\end{array}$ \\
\hline 1986 & $\begin{array}{l}\text { PRFS - Performance-Based } \\
\text { Research Funding System }\end{array}$ & \multicolumn{2}{|l|}{ REA - Great Britain. } \\
\hline 2005 & Hirsch index & $\begin{array}{l}\text { „An index to quantify an individual's } \\
\text { scientific output”, Proceedings of the } \\
\text { National Academy of Sciences of the } \\
\text { USA. }\end{array}$ & (Hirsch, 2005) \\
\hline
\end{tabular}


The concept of scientific productivity has a great importance for scientific and research activity due to the following areas of use of its measurement:

1. Determining the level of development of scientific activity, scientific progress, comparison of the scientific level and determination of research directions;

2. Allocation of funds;

3. Managing public funds, designing the right personnel policy and assessing the effectiveness of the policy;

4. Defining and verifying bibliometrics aws;

5. Determining the area of scientific activity of the entity;

6. Evaluation of scientific units, researchers, scientific journals;

7. Identification of key achievements for the development of science;

8. Analysis of research trends;

9. Observation of scientific development and progress;

10. Identification of scientists and research centres having a significant impact on the development of science.

The evaluation of scientific productivity is multilevel. Analyses and comparisons are made both in the dimension of global systems, which are transnational and supraregional, as well as at the level of national evaluation systems, and as a consequence of the solutions adopted at the level of scientific units (institutional systems). In summary, we can measure scientific productivity at the following levels: I Level: global systems for measuring scientific productivity;

II Level: national systems for measuring scientific productivity;

III Level: institutional systems for measuring scientific productivity.

\section{Scheme of measuring scientific productivity}

The evaluation of scientific productivity is carried out according to Scheme 1.

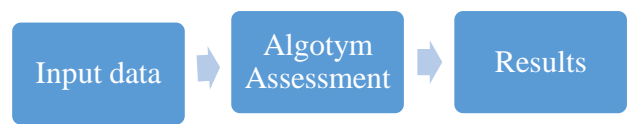

Scheme 1. Scheme of measuring scientific productivity

Source: own study

Input data is the information from:

1. Bibliographic, abstract and bibliometrics databases, among which the following may be distinguished:

- Global and multiple databases: Web of Science, Scopus;

- Global and single databases: Chemical Abstracts Service / SciFinder (chemistry and related fields), ACM Digital Library (information technology and computer science), INSPEC (exact sciences and engineering), MEDLINE (natural sciences with an emphasis on biomedicine and health);

- National bases, usually of onefamily nature: BazEkon, BazTech;

2. Databases related to patents and patent applications, among others Database of the Polish Patent Office, United States Patent and Trademark Office (USPTO), Database of the European Patent Office (EPO);

3. Databases collecting data on individual scientific achievements, e.g. degrees and titles obtained, among others: Polish Science database

4. Databases of financing institutions gathering information on the funds allocated to finance scientific research projects 
5. Data on evaluated scientific institutions from the individual resources of these units.

The algorithm for assessing scientific productivity may be defined as a sequence of actions necessary to determine the level of productivity based on the collected and verified input data.

The result of the algorithm should be an objective evaluation of scientific productivity, which is the basis for evaluation scientific level and decisions regarding the organisation and level of research funding.

\section{Determinants of scientific productivity}

Determinants of scientific productivity constitute a set of factors that have a fundamental impact on its level. During many years of research on scientific productivity and factors affecting its level, numerous dependencies verified by successive researchers have been formulated. Many of them have been related to age and its impact on scientific productivity. The generally formulated thesis is that average productivity increases with age and reaches a peak at some point during the progress on career, and then falls at the end of a scientific career. Most researchers show that the breakthrough point associated with the highest number of published works is around 50 years old. At the same time, the quality of publications increases after the age of 50. The rationale for this dependence is as follows: with age, the accumulation of knowledge and experience and recognition in the scientific community may be observed. On the other hand, it has been shown that recognition in the scientific community affects the higher level of scientific productivity expressed in the number of citations, but it does not matter in the case when the scientific output is measured by the number of published works (Gonzalez-Brambila \& Veloso 2007).

Researchers devote a lot of attention to the place of women in shaping science. Numerous publications confirm that women publish less than men. Differences in the level of scientific productivity of women and men are visible taking into account different measures of productivity: number of publications, citations, number of obtained grants, scientific promotions (Sotudeh \& Khoshian, 2014). An important research problem raised in scientific publications is the attempt to identify the causes of the occurring diversity of scientific productivity due to gender. The most important conclusions emerging from the research are presented in

Table .

Table 4. Causes of lower scientific productivity of women

\begin{tabular}{|l|l|}
\hline \multicolumn{1}{|c|}{ Reasons } & \multicolumn{1}{c|}{ Source } \\
\hline Women stop their careers to have family and children & (Prozesky, 2008) \\
\hline $\begin{array}{l}\text { Having children causes lower scientific productivity and } \\
\text { affects women more than men }\end{array}$ & $\begin{array}{l}\text { (Kyvik \& Teigen, 1996), (Kyvik, 1990) } \\
\text { (Fuchs et al., 2001), (Hunter \& Leahey, } \\
\text { 2010) }\end{array}$ \\
\hline $\begin{array}{l}\text { Women who have children younger than 10 years, } \\
\text { publish significantly less than men }\end{array}$ & (Kyvik, 1990) \\
\hline Women start their careers at a later age than men & (Karamessini, 2004), (Prozesky, 2008) \\
\hline Men are preferred to scientific positions & (Arensbergen et al., 2012) \\
\hline
\end{tabular}


Table 4. Causes of lower scientific productivity of women (continued)

\begin{tabular}{|c|c|}
\hline Reasons & Source \\
\hline $\begin{array}{l}\text { Permanent discrepancies in the level of remuneration } \\
\text { between men and women }\end{array}$ & (Ginther, 2003) \\
\hline Weakened network of scientific cooperation & (Bozeman \& Sooho, 2003) \\
\hline $\begin{array}{l}\text { Differences in the level of productivity exist but in the } \\
\text { case of the younger generation of researchers they } \\
\text { disappear }\end{array}$ & (Arensbergen et al., 2012) \\
\hline
\end{tabular}

Scientific promotion and seniority are important factors influencing the level of scientific productivity. The desire to develop and advance in science is a strongly motivating factor. In order to achieve higher scientific positions, an employee must have the scientific achievements that will ensure his or her academic advancement. Seniority is associated with experience, recognition in the environment, which may positively affect the level of scientific productivity. The results of the research regarding the discussed determinants are presented in Table .

Table 5. Promotion and seniority as determinants of scientific productivity

\begin{tabular}{|l|l|}
\hline \multicolumn{1}{|c|}{ Conclusions } & \multicolumn{1}{c|}{ Source } \\
\hline Seniority has a positive effect on scientific productivity & $\begin{array}{l}\text { (Abramo et al., 2011), (McNally, 2010), } \\
\text { (Puuska, 2010) }\end{array}$ \\
\hline $\begin{array}{l}\text { Scientific advancement positively influences scientific } \\
\text { productivity }\end{array}$ & $\begin{array}{l}\text { (Aksnes et al., 2011) (Puuska, 2010), } \\
\text { (Abramo et al., 2011) }\end{array}$ \\
\hline $\begin{array}{l}\text { Employment over a longer period of time in the same } \\
\text { position has a negative impact on scientific productivity }\end{array}$ & (Coupe et al., 2006) \\
\hline Scientists in lower positions are more productive than others & (Coupe et al., 2006) \\
\hline $\begin{array}{l}\text { The number of published works is stopped immediately } \\
\text { after the promotion }\end{array}$ & (Puuska, 2010), (Tien, 1996) \\
\hline
\end{tabular}

Source: own study

The general differences in the outcomes of research on scientific productivity result from the fact that research is carried out in various conditions influenced by: the country and the scientific environment in which research is carried out, the period and scope of data covered by the research and the scientific discipline. One of the most frequently compared aspects is the scientific discipline. Differences in the level of productivity among a variety of scientific disciplines result from differences in their specificity. In scientific disciplines in which the dynamics of change is large and new research methods using new technologies are often introduced, scientists with age may have difficulty adapting to rapidly changing conditions. Disciplines in which development is stable and not strongly dependent on technological progress, scientists are able to maintain a high level of productivity throughout the entire duration of the scientific work. Such features are characterised by scientific disciplines in the social sciences and humanities. 
Considering the multifaceted nature of determinants, the author has made the following classification of factors relevant to the level of scientific productivity, which is presented in Table 6 .

Table 6. Determinants of scientific productivity

\begin{tabular}{|l|l|}
\hline \multicolumn{1}{|c|}{ Factors } & \multicolumn{1}{c|}{ Determinants } \\
\hline $\begin{array}{l}\text { Individual } \\
\text { factors }\end{array}$ & $\begin{array}{l}\text { Age, gender, marital status, } \\
\text { number of children, experience } \\
\text { (seniority), academic title and } \\
\text { degree, professional position }\end{array}$ \\
\hline $\begin{array}{l}\text { Institutional } \\
\text { factors }\end{array}$ & $\begin{array}{l}\text { Institutional environment, } \\
\text { research funding system, } \\
\text { evaluation system for scientific } \\
\text { activity, structure and size of } \\
\text { the unit, didactic activity }\end{array}$ \\
\hline $\begin{array}{l}\text { Scientific } \\
\text { cooperation }\end{array}$ & $\begin{array}{l}\text { Number of co-authors of the } \\
\text { publication, participation in } \\
\text { research teams }\end{array}$ \\
\hline
\end{tabular}

Individual factors are related to the ongoing biological processes and individual decisions related to professional development or achieving a certain social status. Institutional factors are controlled at the university level or at the state level. Institutional factors cover such aspects as working conditions, work organisation, technical equipment, evaluation procedures, human resources policy, and the motivation system of the university. The third group of factors refers to scientific cooperation, which is associated with individual factors and the conditions that encourage its adoption, created both by universities and the state.

\section{Research Methodology}

The main purpose of the publication is cognitive and focuses on the analysis of factors determining the individual scientific productivity of employees of the Cracow University of Economics. The choice of variables for the phenomenon analysed in the work is based on substantive knowledge supported by the analysis of the subject literature and available data sets collecting information about University employees. Based on the literature review concerning research on scientific productivity and available databases, the analysis has been carried out, concerning such determinants as: gender, age, number of children, academic degrees and titles, position, number of didactic hours, department and faculty where the employee is employed.

Scientific achievements of researchers, employed at the Cracow University of Economics in the years 2004-2015, have been divided into the following groups of scientific publications: articles in scientific journals, scientific monographs, chapters in scientific monographs, chapters in conference materials. The analysis of the determinants of scientific productivity has been carried out separately for each of the mentioned groups, using the following measures of scientific productivity:

1. The absolute number of publications

2. Participation in the creation of the publication

For scientific productivity expressed in the absolute number of items, the following assumptions have been made: each employee is assigned a given publication position, regardless of the actual number of authors of the publication. The total number of publications for one year is the number of employee authorship or co-authorship publications released in the year.

The number of co-authors has been taken into account for the scientific productivity expressed in the value of participation in the creation of the scientific publication. In connection with the above, the number of publications is weighted with the employee's participation in its creation (employee's participation in the creation of the publication is defined as $\frac{1}{n}$, where $n$ is the number of publication authors). The total employee's participation in the creation of the 
publication, attributable to one year, has been determined by the formula participation:

$$
Y_{t}=\sum_{i=1}^{k} \frac{1}{n_{i}}
$$

where:

$Y_{t}$ - the total employee participation in the publication designated for the year $\mathrm{t}$

$k$ - the number of articles written or coauthored by the employee designated for the year $\mathrm{t}$

$n_{i}$ - the number of authors of the i-th article.

In order to identify determinants of scientific productivity, the analysis of variance has been used. Based on the analysis of the literature related to the one-way analysis of variance, the research has been carried out in the following steps:

1. Division of observations into groups based on an independent variable (e.g. gender)

2. Verification of the assumptions of a one-way analysis of variance:

a. Test the assumption of normality Shapiro-Wilk's test

b. Uniformity of variance: Bartlett's test (in the case of normal distribution), Levene'a test (in the case of non-fulfilment of assumptions about normality)

3. In the case of the fulfilment of the assumptions, ANOVA is used

4. If the assumptions of ANOVA are not met, non-parametric tests are used: Kruskal-Wallis test for more than two groups or U MannaWhitneya test for exactly two groups.

\section{Results}

The author has analysed the following determinants affecting scientific productivity in the period from 2004 to 2015 year: gender, age, number of children, degrees and academic titles, position, number of teaching hours, faculty, department.
In the analysed period, the highest percentage of women among employees is $45.5 \%$ in the year 2008 under consideration. Starting from this year, despite the increase in the number of employees, the percentage of employed women has decreased and in 2015 amounted to $42.28 \%$. In each of the analysed groups of scientific publications, gender is the determinant of individual scientific productivity. The average number of publication items in the analysed groups is in each case higher for men than for women. The results of the analysis confirm the theses presented in the world literature about the prevalence of men over women as authors of scientific publications. During the analysed period, women employed in didactic positions prevail. In accordance with the internal regulations of the Cracow University of Economics related to the financing of research from statutory subsidies, people employed in didactic positions cannot not apply for co-financing of scientific publications from the above source.

The analysis of the scientific productivity due to age groups also determines the level of productivity in each of the analysed groups of scientific publications. The highest level of scientific productivity has been demonstrated for the range between 40 and 50 years of age. A similar tendency, as in the case of articles, is formed in the group of chapters in scientific monographs. The intervals between 40 and 50 years of age recorded the highest level of productivity both in the case of number and participation in the creation of chapters in monographs. In the case of the number of scientific monographs, the highest level of productivity occurs in the range between 50 55 years of age, while the participation in the creation of a monograph in the ranges from 40 to 60 years of age. In the case of the number of chapters in conference materials, one can point to two range periods associated with the highest productivity, from 40 to 45 years of age and 55-60 years of age. In the case of participation in the publication creation, the highest level of productivity concerns the employee's age in the ranges 
from 40 to 45 years and from 50 to 60 years. The analysed results coincide with the theses presented in the world literature, where it has been proven that average productivity increases with age and reaches the peak at some point during the career, and then falls at the end of a scientific career.

In the case of the number of children, in each of the analysed groups of scientific publications, except for the authorship of scientific monographs, the number of children constitutes the determinant of individual scientific productivity. In each of the analysed publication groups, the lowest scientific productivity concerns people who do not have children. As the analysis has shown, these are mainly people who start their careers, with little experience, and as the literature on the subject shows, experience is one of the important factors affecting the level of scientific productivity. In the case of publishing groups where it has been proven that the number of children is a determinant of productivity, its highest level is recorded in the case of having one child or two children.

Employees of the Cracow University of Economics are employed in didactic positions or scientific positions. Duties resulting from a didactic position concern only didactic activity. The duties of an employee employed in both a didactic and scientific position include both carrying out lectures and the scientific activity. In each of the analysed groups of scientific publications, the position held is the determinant of individual scientific productivity. The highest level of scientific productivity concerns persons employed as a full professor, the only exception is the group associated with the number of chapters in conference materials, in which the highest productivity is indicated for people employed as an associate professor. The lowest level of productivity is characteristic for employees employed in didactic positions: a lecturer and senior lecturer, and the nature of the position held has key significance in the context of fulfilling duties other than scientific activity.

The conducted research proves that the degree and the academic title constitute the determinant of individual scientific productivity. In each of the analysed publication groups, the lowest level of scientific productivity concerns people with master's degree. This result of the analysis confirms the thesis that in the case of employees of the University of Economics experience has a major impact on the level of productivity. The above thesis is also confirmed by the results related to the development of scientific productivity at the highest level, which refers to employees with the academic title of professor and, secondly, people with the degree of doctor habilitated. It should also be noted that within the group of people with a doctoral degree, which is the third group in terms of productivity level, there is a significant number of employees employed in didactic positions who are characterised by low scientific activity due to obligations resulting from the didactic position and more difficult access to funds allocated to scientific activities.

In each of the analysed groups of scientific publications, the number of didactic hours carried out is a determinant of individual scientific productivity. From the conducted research, a certain relationship may be deduced: the number of people with the lowest didactic load is characterised by the lowest average level of productivity, while people with a didactic load above 600 hours per year represent a group of employees with the highest average level of productivity.

The analyses related to the organisational structure of the university have shown that both the faculty and the department are determinants of scientific productivity.

The summary of the analysis results are contained in Table 7. 
Table 7. Determinants of scientific productivity of researchers from the Cracow University of Economics

\begin{tabular}{|c|c|c|c|c|c|c|c|c|}
\hline \multirow[b]{2}{*}{ Determinant } & \multicolumn{2}{|c|}{$\begin{array}{c}\text { Articles in } \\
\text { scientific } \\
\text { journals }\end{array}$} & \multicolumn{2}{|c|}{$\begin{array}{c}\text { Scientific } \\
\text { monographs }\end{array}$} & \multicolumn{2}{|c|}{$\begin{array}{l}\text { Chapters in } \\
\text { scientific } \\
\text { monographs }\end{array}$} & \multicolumn{2}{|c|}{$\begin{array}{c}\text { Chapters in } \\
\text { conference } \\
\text { materials }\end{array}$} \\
\hline & $\begin{array}{l}\dot{\bar{D}} \\
\text { 壳 }\end{array}$ & 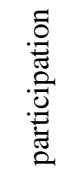 & 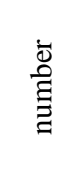 & 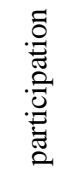 & 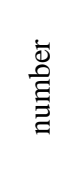 & 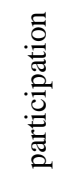 & 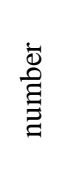 & 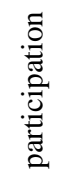 \\
\hline Gender & Yes & Yes & Yes & Yes & Yes & Yes & Yes & Yes \\
\hline Age & Yes & Yes & Yes & Yes & Yes & Yes & Yes & Yes \\
\hline Number of Children & Yes & Yes & No & No & Yes & Yes & Yes & Yes \\
\hline Academic Degrees and Titles & Yes & Yes & Yes & Yes & Yes & Yes & Yes & Yes \\
\hline Position & Yes & Yes & Yes & Yes & Yes & Yes & Yes & Yes \\
\hline Number of Didactic Hours & Yes & Yes & Yes & Yes & Yes & Yes & Yes & Yes \\
\hline Faculty & Yes & Yes & Yes & Yes & Yes & Yes & Yes & Yes \\
\hline Department & Yes & Yes & Yes & Yes & Yes & Yes & Yes & Yes \\
\hline
\end{tabular}

Source: own study

\section{Conclusions}

Both individual and institutional factors influence the level of scientific productivity. Practically in each of the publication groups, the influence of the studied factors on the number and participation in the creation of publishing positions has been noticed. The only exception is the number and participation in the creation of the monograph. The conducted analysis shows that the number of children does not influence the number and participation in the creation of the scientific monograph.

The obtained results allow to formulate certain regularities that refer to the employees of the Cracow University of Economics:

1. The results of the analysis confirm the theses presented in the world literature about the advantage of the level of scientific productivity of men over women;
2. Employment in didactic positions negatively affects the level of scientific productivity;

3. Women constitute the majority of employees employed in didactic positions;

4. Average productivity increases with age and reaches a peak at some point during the course of a career and then falls at the end of a scientific career;

5. Having children and parenting responsibilities do not negatively affect the level of scientific productivity;

6. The level of scientific productivity depends on the employee's experience;

7. The number of didactic hours has no negative impact on the level of scientific productivity;

8. Employees of individual faculties and departments are characterised by different levels of scientific productivity. 
It should be emphasised that an important element of scientific development is the implementation of a properly constructed university policy taking into account individual and institutional factors of scientific development. The results of the conducted research indicate that it is possible to shape the scientific productivity of employees. This is evidenced by the significant impact of the closest employee environment (represented by the faculty and department) on productivity.

Undoubtedly, the difficulty in carrying out the research has been to gather such extensive research input from a period of 12 years of scientific activity of the employees of the Cracow University of Economics, including the lack of one coherent database gathering information about employees or the lack of historical data in available systems.

In the author's opinion, issues related to the identification of determinants affecting the level of scientific productivity constitute an extremely interesting and extensive research issue. The analyses conducted in the publication do not exhaust the topic related to the concept of productivity, especially in the context of Polish scientists and Polish scientific institutions. The presented considerations and analyses may form the basis for further research, characterised by different input data, taking into account points awarded for publications, different selection of a set of determinants, or analyses going beyond one scientific institution. The author considers the research on the development of scientific productivity in the conditions created by new statutory solutions in the area of higher education in Poland, in particular in the light of the new principles of evaluation of higher education units as a rather interesting research direction.

Acknowledgment: The research has been carried out as part of a research initiative financed by the Ministry of Science and Higher Education within "Regional Initiative of Excellence" Programme for 2019-2022. Project no.: 021/RID/2018/19. Total financing: PLN 11897 131,40.

\section{References:}

Abramo, G., D’Angelo, C. A., \& Di Costa, F. (2011). Research productivity: Are higher academic ranks more productive than lower ones? Scientometrics, 88(3), 915-928. https://doi.org/10.1007/s11192-011-0426-6

Aksnes, D. W., Rorstad, K., Piro, F., \& Sivertsen, G. (2011). Are female researchers less cited? A large-scale study of Norwegian scientists. Journal of the American Society for Information Science and Technology, 62(4).

Allison, P. D., \& Stewart, J. A. (1974). Productivity Differences Among Scientists: Evidence for Accumulative Advantage. American Sociological Review, 39(4), 596-606.

Arensbergen, P. van, Weijden, I. van der, \& Besselaar, P. van den. (2012). Gender differences in scientific productivity: a persisting phenomenon? Scientometrics, 93(3), 857-868.

Bozeman, B., \& Sooho, L. (2003). The Impact of Research Collabor ation on Scientific Productivity. Social Studies of Science, 35(5).

Cattell, J. M. (1903). Statistics of American Psychologists. American Journal of Psychology, 14(3/4), 310-328.

Cattell, J. M. (1906). American Men of Science: A Biographical Directory. New York: The Science Press.

Cattell, J. M. (1910). A Further Statistical Study of American Men of Science. Science, 4(827), 633-648 
Cattell, J. M. (1915). Families of American Men of Science: Origin, Heredity and Performance. Popular Science Monthly.

Cole, J., \& Cole, S. (1973). Social Stratification in Science. Chicago: University of Chicago Press.

Coupe, T., Smeets, V., \& Warzynski, F. (2006). Incentives, Sorting and Productivity Along the Career: Evidence from a Sample of Top Economists. Journal of Law, Economics, and Organization, 22(1).

Fox, M. F. (1983). Publication Productivity among Scientists: A Critical Review. Social Science Information, 13, 285-305.

Fuchs, S., Stebut, J., \& Allmendinger, J. (2001). Gender, science, and scientific organizations in Germany. Minerva, 39(2), 175-201. https://doi.org/10.1023/A:1010380510013

Galton, F. (1874). English Men of Science. London: Mcmillan\&Co.

Galton, F. (1883). Inquiries into Human Faculties and its Development,. London: Mcmillan\&Co.

Garfield, E. (1955). Citation Indexes for Science A New Dimension in Documentation through Association of Ideas Science. Science, 122(3159), 108-118.

Gaston, J. (1970). The Reward System in British Science. American Sociological Review, 35(4), 718732.

Gaston, J. (1978). The Reward System in British and American Science. New York: John Wiley \& Sons Inc.

Ginther, D. K. (2003). Is MIT an Exception? Gender Pay Differences in Academic Science. Bulletin of Science, Technology \& Society, 23(1), 21-26.

Godin, B. (2006). On the origins of bibliometrics. Scientometrics, 68(1), 109-133.

Godin, B. (2007). From eugenics to scientometrics: Galton, Cattell, and men of science. Social Science Information, 37(5), 691-728.

Godin, B. (2009). The value of science: changing conceptions of scientific productivity, 1869 to circa 1970. Social Science Information, 48(4).

Gupta, D. K. (1987). Lotka's law and productivity patterns of entomological research in Nigeria for the period, 1900-1973. Scientometrics, 12(1-2), 33-46. https://doi.org/10.1007/BF02016688

Gupta, D. K. (1989). Lotka's Law and Its application to Author Productivity Distribution of Psychological Literature of Africa, 1966-1975. Herald of Library Science, 28(1-2).

Hirsch, J. E. (2005). An index to quantify an individual's scientific research output. Proc Natl Acad Sci U S A, 102(46).

Hunter, L. A., \& Leahey, E. (2010). Parenting and research productivity: New evidence and methods. Social Studies of Science, 40(3), 433-451. https://doi.org/10.1177/0306312709358472

Karamessini, M. (2004). Women's representation and progression in science careers in Greece. Athens: KETHI Research Centre for Gender Equality, 1-26.

Kumar, N. (2010). Applicability to Lotka's law to research productivity of Council of Scientific and Industrial Research (CSIR), India. Annals of Library and Information Studies, 57(March), $1-5$.

Kwiek, M. (2015). Nierówności w produkcji wiedzy naukowej: rola najbardziej produktywnych naukowców w 11 krajach europejskich. CPP RPS, 88. 
Kyvik, S. (1989). Productivity differences fields of learning, and Lotka's law. Scientometrics, 15, 205-214. Retrieved from http://www.springerlink.com/index/X4442327WQ358X13.pdf

Kyvik, S. (1990). Age and scientific productivity. Differences between fields of learning. Higher Education, 19(1), 37-55. https://doi.org/10.1007/BF00142022

Kyvik, S, \& Teigen, M. (1996). Child care, research collaboration, and gender differences in scientific productivity.pdf. Science, Technology, \& Human Values, 21, 54-71.

Lotka, A. (1926). The Frequency Distribution of Scientific Productivity. Journal of the Washington Academy of Science, 16(12).

McNally, G. P. (2010). Scholarly productivity, impact, and quality among Academic Psychologists at Group of Eight Universities. Australian Journal of Psychology, 62(4), 204215. https://doi.org/10.1080/00049531003667406

Merton, R. K. (1968). The Matthew Effect in Science. The reward and communication systems of science are considered. Science, 159(3810), 56-63.

Mittermeir, R., \& Knorr, D. K. (1979). Scientific productivity and accumulative advantage: a thesis reassessed in the light of international data. $R$ and $D$ Management, (Special Issue), 235239.

Murphy, L. J. (1973). Lotka's law in the humanities? Journal of the American Society for Information Science, 24(6), 461-462.

Nowak, P. (2008). Bibliometria. Webometria. Podstawy. Wybrane zastosowania (Wydawnictw).

OECD. (1962). The Measurement of Scientific and Technical Activities: Proposed Standard Practice for Surveys of Research and Experimental Development.

Pao, M. L. (1986). An empirical examination of Lotka's law. Journal of the American Society for Information Science, 37(1), 26-33.

Patraa, S. K., \& Chandb, P. (2006). Library and Information Science Research in India: A bibliometric study. Annals of Library and Information Studies, 54, 219-223.

Pillai Sudhier, K. (2013). Lotka's Law and patterns of author productivity in the Area of physical Review. Journal of Library\& Information Technology, 33(6).

Price, D. J. de S. (1963). Little science, big science. New York: Columbia Univ. Press.

Pritchard, A. (1969). Statistical bibliography or bibliometrics? Journal of Documentation, 25, 348-349.

Prozesky, H. (2008). A career-history analysis of gender differences in publication productivity among South African academics. Science Studies, 21(2), 47-67.

Puuska, H. M. (2010). Effects of scholar's gender and professional position on publishing productivity in different publication types. Analysis of a Finnish university. Scientometrics, 82(2), 419-437. https://doi.org/10.1007/s11192-009-0037-7

Radhakrishnan, T., \& Kernizan, R. (1979). Lotka's Law and Computer Science Literature. Journal of the American Society for Information Science, 30(1), 51-54.

Ramsden, P. (1994). Describing and explaining research productivity. Higher Education, 28, 207-226.

Schumpeter, J. (1939). Business Cycles: A Theoretical, Historical, and Statistical Analysis of the Capitalist Process. New York, Toronto, London: McGraw-Hill Book Company.

Shenhav, Y., \& Haberfeld, Y. (1988). The various faces of scientific productivity: a contingency analysis. Quality and Quantity, 22(4), 365-380. https://doi.org/10.1007/BF00171627 
Solow, R. M. (1957). Technical Change and the Aggregate Production Function. The Review of Economics and Statistics, 39(3), 312-320.

Sotudeh, H., \& Khoshian, N. (2014). Gender differences in science: the case of scientific productivity in Nano Science \& Technology during 2005-2007. Scientometrics, 98(1), 457472.

Sridhar, S. (2009). What Motivates Faculty To Take Up Research Activities?

Stephan, P. E., \& Levin, S. G. (1992). Striking the Mother Lode in Science: The Importance of Age, Place, and Time. Oxford: Oxford University Press.

Tien F. B. R. (1996). Faculty Rank System, Research Motivation, and Faculty Research Productivity: Measure. Journal of Higher Education, 67(1), 2-22.

Vilachy, J. (1978). Frequency distributions of scientific performance a bibliography of Lotka's law and related phenomena. Scientometrics, 1 .

\author{
Monika Hamerska \\ Cracow University of \\ Economics, College of \\ Management Sciences and \\ Quality, Department of \\ International Management, \\ 27 Rakowicka Street, 31-510 \\ Krakow, Poland, \\ monika.hamerska@uek.krakow.pl
}




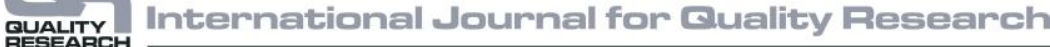

